\title{
CONTENT VALIDITY AND RELIABILITY ANALYSIS OF INTEGRATED ISLAMIC-SCIENCE TEST INSTRUMENT TO MEASURE THE STUDENT'S CRITICAL THINKING ABILITY
}

\author{
Muhammad Fajrul Bahri \\ Yogyakarta State University, Yogyakarta \\ e-mail: fajrulbahri17@gmail.com \\ Supahar \\ Yogyakarta State University, Yogyakarta \\ e-mail:pahar.fis@gmail.com
}

\begin{abstract}
This research is aimed to asses the validity and reliability of Islamic-science integrated test instrument. The instrument was formed in multiple-choice test instrument which is regarded as appropriate to assist student critical thinking ability. The validity of the instrument and its reliability were assessed quantitively. While Aiken's $\mathrm{V}$ was used for assessing content validity, and Alpa Cronbach was used for assessing content reliability. In terms of Item Response Theory, it was assessed through the test I Function information and Standard Error of Measurement (SEM). The result of developing Islamic-science integrated test instrument to measure critical thinking ability was formed in the form of closed-minded multiple choice that consisting of two test packages. The total test items on the instrument are 45 items consisting of 25 items with 5 shared items (anchor). Estimation of the validity test instrument obtained an index ranging from 0.75 to 1 . According to classical test theory, the coefficient of reliability was 0.70 and according to the total function information and Standart Error of Measurement, the test instrument was suitable for rangeability from 1.75 to +3 . Thus, the test instrument is proved reliable and valid. A total of seven teachers using the declared that the test instrument is appropriate to use in measuring learning outcomes, especially the critical thinking abilities of the student.
\end{abstract}

Keywords: Validity, Reliability, Islamic- science integracy

\begin{abstract}
Abstrak
Penelitian ini bertujuan untuk menganalisis konten validitas dan reliabilitas dari intrumen tes terintegrasi agama dan sains. Konten validitas dan reliabilitas dianalisis secara kuantitatif. Pendekatan kuantitatif untuk konten validitas menggunakan Aiken's $V$, sedangkan untuk konten reliabilitas menggunakan Alpha Cronbach dan secara teori respon butir menggunakan fungsi informasi dan kesalahan pengukuran. Hasil pengembangan berupa instrumen tes terintegrasi agama dan sains untuk mengukur kemampuan berpikir kritis berupa tes pilihan ganda beralasan tertutup yang terdiri atas dua paket tes. Total item tes pada instrumen sebanyak 45 item yang terdiri dari 25 item dengan 5 item bersama (anchor). Estimasi validitas instrumen tes menggunakan formula Aiken diperoleh rentang indeks antara 0,75 sampai 1. Estimasi reliabilitas tes menurut teori tes klasik ditunjukkan oleb koefisien Alpha Cronbach sebesar 0,70 dan menurut kurva total fungsi informasi dan SEM yang berdasar pada teori respon butir (IRT) instrumen tes cocok untuk rentang kemampuan -1,75 sampai +3 . Dengan demikian instrumen tes terbukti valid dan reliabel. Sejumlah tujuh guru pengguna instrumen tes menyatakan babwa instrumen tes layak digunakan dalam pembelajaran. Dengan demikian instrumen tes cocok dan layak digunakan untuk mengukur hasil pembelajaran khususnya pada kemampuan berpikir kritis peserta didik.
\end{abstract}

Kata Kunci: V aliditas, Reliabilitas, Integrasi Islam-sain

\section{Background}

At present, the dynamics of learning education always changes in line with development times. Ideal learning requires the teacher to develop learning in a more conventional direction. The Constitution Number 20th in 2003 about the national education system defined an ideal learning activity involves interaction between student, teacher, and learning resources in learning 
education. ${ }^{1}$ This idea leads to an understanding that learning should be regarded as a process in which transferring knowledge from teacher to student has happened. This urges a teacher to creative preparing an appropriate instrument for measuring learning outcomes. Generally, Anderson and Krathwohl divided the cognitive abilities of the student into six parts, namely remembering, understanding, applying, analyzing, evaluating, and creating. The six levels of cognitive ability then divided into two levels of thinking skills, namely lower-order thinking skills (that are remembering, understanding, and applying), and high order thinking skills (that are analyzing, evaluating, and creating). ${ }^{2}$

The differences in cognitive abilities among student encourage teachers to develop learning at high-level abilities. It is most important for the student to acquire the highlevel ability, especially in critical thinking skill. Quitadamo et. al defined critical thinking is a purposeful self-regulation assessment process that encourages problem-solving and decision making, or the engine that encourages how we decide what to do or believe in a particular context ${ }^{3}$. More research defined about the critical thinking ability, Yusri implies the critical thinking skills are important for a student especially in natural science, even from basic education, which can be acquired through the

${ }^{1}$ Team Publish, Salinan Undang- Undang No. 20 Tabun 2003 tentang Sistem Pendidikan Nasional Jakarta: Nusa Press, 2017), p. 3

${ }^{2}$ L. W., Anderson, D. R, Krathwohl, Kerangkea Landasan Untuk Pembelajaran, Pengajaran, Dan Asesmen (Revisi Taksonomi Pendidikan Bloom), cetakan kedua (terjemahan Agung Prihantoro), (Yogyakarta: Pustaka Pelajar, 2017), p. 105

${ }^{3}$ Ian Quitadamo and others, 'Community-Based Inquiry Improves Critical Thinking in General Education Biology', CBE Life Sciences Education, 7.3 (2008), 327-37 <https://doi.org/10.1187/cbe.07-11$0097>$. implementation of scientific learning model. ${ }^{4}$ Similarly, with that statement, Istianah explains that critical thinking skills are tended in mathematics and natural science, where, using a particular model can improve the critical thinking skills in Mathematics learning ${ }^{5}$.

Unfortunately, approaches that implement in Islamic education subjects do not encourage and train the student to use critical thinking skills. Mumtahanah explains, on reality, general teachers still using conventional methods in his leaning, which is make the teacher always dominates in the teaching and learning process. Learning situations where the teacher is the central point making the role of student becomes very small. They were just sitting, listening to information provided by the teacher, recording what the teacher delivered, and memorizing what he recorded ${ }^{6}$.

Kunter et al. state that teacher education is an important variable as a quality of control that has a contribution in achieving the success of learning to achieve the goals, the teacher who teaches the subject must be in line with his field ${ }^{7}$. It is important to needed critical thinking for making sure the learning has getting the best achievement. Pradana et. al imply one of the demands that must be

${ }^{4}$ Yusri, 'Keterkaitan Scientific Learning dengan Kemampuan Berpikir Kritis (Kajian Proses Pembelajaran di Sekolah Dasar Budi Mulia Dua Sedayu Bantul)' \{unpublished magister thesis, Program Pascasarjana UIN Sunan Kalijaga, Yogyakarta, 2015\}, p. 15.

5 Euis Istianah, 'Meningkatkan Kemampuan Berpikir Kritis dan Kreatif Matematik dengan Pendekatan Model Eliciting Activities (MEAS) pada Siswa SMA', Infinity Journal, 2.1 (2013), 43 <https://doi.org/10.22460/infinity.v2i1.23>.

6 Nurotun Mumtahanah, 'Meningkatkan Kemampuan Berpikir Kritis Siswa Melalui Metode Cooperative Learning dalam Pembelajaran PAI', Al Hikmah: Jurnal Studi Keislaman, 3.1 (2013), 4.

7 Mareike Kunter and others, 'Professional Competence of Teachers: Effects on Instructional Quality and Student Development', Journal of Educational Psychology, $\quad 105.3 \quad$ (2013), $\quad 805-20$ <https://doi.org/10.1037/a0032583>. 
fulfilled on current learning is critical thinking ability $^{8}$. The learning that directs student to develop critical thinking skills will make student compete in the global arena.

Integrated of Islamic-science requires the student to develop knowledge to higher-order thinking skills. The integration is supposed to train the student for increasing higher thinking skills, especially in critical thinking ability, since it leads them to engage in learning activities in which they should aware of links between science or a scientifical phenomenon and religious values. Hove imply the using of critical thinking strategies in the high school classroom can improve student appearance. The combination of Islamic and science-based learning will create a critical thinking ability because the student is expected to be able to find links between Islamic material learning and the state of science learning that surrounds them as well as those that have been proven.

This high level of ability is then expressed through the domain of critical thinking skills in order to understand learning material that is integrated into Islamic-science. in Islamic Islamic learning. It is necessary to have an instrument model developed in compiling an appropriate test instrument to measure critical thinking ability. Wagner implies one of the skills needed by the student in order to survive in the 21 st century is critical thinking skills and solve the problem ${ }^{10}$.

The test generally assesses the achievement of students' competence on the cognitive dimension. Integrated of Islamic-

${ }^{8}$ Shan Duta Sukma Pradana, Parno Parno, and Supriyono Koes Handayanto, 'Pengembangan Tes Kemampuan Berpikir Kritis Pada Materi Optik Geometri Untuk Mahasiswa Fisika', Jurnal Penelitian dan Evaluasi Pendidikan, $21.1 \quad$ (2017), 51 <https://doi.org/10.21831/pep.v21i1.13139>.

${ }^{9}$ G., Hove, 'Developing Critical Thinking Skills in The High School English Classroom' \{unpublished magister thesis, University of Wisconsin-Stout, 2011\}, p. 32 .

10 T., Wagner, The Global Achievment Gap (New York: Basic Book, 2008), p. 14. science in Islamic education learning to measure critical thinking skills can develop with a test instrument. According to Mardapi, the test is an instrument used to make the measurement. ${ }^{11}$ Azwar describes the test as a question set devised to uncover certain attributes through response to the question ${ }^{12}$ Similarly, Gronlund \& Linn in Suwarto defined test was an instrument or systematical procedures that making to measuring a sample of behaviour. Similarly with that, Cronbach implies test is a systematic procedure for viewing out a person's behaviour and explain it with the aid of a numerical scale or a categorysystem $^{13}$. The purpose of the test is to measure the achievement of learning outcomes or competencies to be achieved by the student. It is necessary to make a standard test to assess critical thinking ability based on integrated Islamic-science test.

\section{The Study of Reliability and Validity} Study of Reliability

The results of the test can be trusted if the measuring instrument used reliably, such as able to produce a careful score with minor measurement errors. Reliability of test measurement is estimated through the computation of reliability coefficients and standard error measurement in accordance with specific analytical procedures. ${ }^{14}$ Reliability similarly with the consistency of student scores that approye alternative forms of the same test. Due to differences in the exact content are assessed on alternative types, environmental variables such as fatigue or lighting, or student errors in responding, there are no two tests

11 Djemari Mardapi, Pengukuran, Penilaian dan Evaluasi Pendidikan (Yogyakarta: Parama Publishing, 2016), p. 94.

12 S., Azwar, Constructing Psychological Scale (Yogyakarta: Pustaka Pelajar, 2017), p. 6.

13 S Suwarto, 'Pengembangan Tes Ilmu Pengetahuan Alam Terkomputerisasi', Jurnal Penelitian Dan Evaluasi Pendidikan, 21.2 (2017), 153 <https://doi.org/10.21831/pep.v21i2.13144>.

${ }^{14}$ Azwar 
that will consistently produce identical results. This is true regardless of how similar the two are. In fact, even the same test given to the same student category the day after will produce two sets of scores that don't coincide perfectly. Obviously, when we conducted two tests that included the same material, we preferred similar student scores. The more the value is, the more reliable the test score is ${ }^{15}$

In order to properly use, a good test instrument should be valid and reliable. A set of an instrument of measuring must have high consistency if the instrument of measure is carried out repeatedly and giving the same results. Reliability applies to the level of a test device, can't valid for each test item composing a measurement instrument. ${ }^{16}$ It is widely known that reliability is one of the basic criteria for a research instrument can be accepted. Reliability supports the validity of a test instrument. Particularly, validity was related to the accuracy of the result measurement in the ability of the test that measured. Therefore, it is important to assist in the reliability of an instrument. steps for resolving reliability can be finished manually or assisted by a computer program. According to Suryabrata, there are several techniques for measuring reliability include test repetition techniques, parallel test, Halves, Rulon formulas, Hoyt formulas, Kuder-Richardson, Kappa coefficients, Cronbach Alpha, etc. ${ }^{17}$

Cronbach's alpha is a popular estimator which underestimates the reliability of a test. ${ }^{18}$ In line with this assertion, Mardapi ${ }^{19}$ and

15 Craig S., Wells, James A. Wollack, $A n$ Instructor's Guide to Understanding Test Reliability: Testing \& Evaluation Services (UK: University of Wisconsin, 2003), p. 2.

${ }^{16}$ B., Subali, Pengembangan Tes: Beserta Penyelidikan Validitas dan Reliabilitas Secara Empiris (Yogyakarta: UNY Press, 2016), p. 60.

17 S., Suryabrata, Pengembangan Alat Ukur Psikologi, edisi ketiga (Yogyakarta: Penerbit Andi, 2005), p. 30

18 Subali.

${ }^{19}$ Mardapi
Azwar ${ }^{20}$ describe through the reliability estimation using the Cronbach formula, the actual reliability is greater than or equal to the calculated $\alpha$-coefficient. If the $\alpha$-coefficient is of high value, then there is a real possibility of reliability even higher, but if it is in low-value there is a probability of unreliability or simply unfulfilled assumptions of parallel tests $(\tau$ equivalent) because $\alpha$-coefficient ignore that one. The value of the recommended construct reliability coefficient is above $0.7 .^{21}$ Researchers who get reliability coefficient score below 0.7 are expected to modify the measurement model they developed.

Reliability on Item Response Theory (IRT) is expressed by the index of separation of items (item separation) and index of person separation (case/person separation). The item separation shows how the sample is scattered along the linear scale, while the person separations show how trusted the arranged test reach from high ability to low ability of individuals. In addition, the reliability in the Item Response Theory was expressed by the information function, which is a relation among the test function information with a standard error of measurement (SEM). Based on a graph of the test information function and standard error of measurement, it is known that the developed test is fit with certain ability.

\section{Study of Validity}

Aiken proposed the concept of content validity more detailed. The detail was seen from the standard validity which is influenced by the number of rater and the rating scale ${ }^{23}$.

${ }^{20}$ Azwar.

21 J.F., Hair, et.al., Multivariate Data Analysis 7th Edition (New York: Pearson Prentice Hall, 2010), p. 125. 22 Mardapi.

23 Lewis R. Aiken, 'Three Coefficients for Analyzing the Reliability and Validity of Ratings', Educational and Psychological Measurement, 45.1 (1985), 131-42

<https://doi.org/10.1177/0013164485451012>. 
Retnawati $^{24}$ and Widoyoko ${ }^{25}$ also explain Validity is a degree to which an interpretation is properly supported by empirical facts and theories. An instrument is considered as valid as it can be used in order to accurately measure something that is supposed to measure. In other words, validity is related to "accuracy" with measuring instrument. A test as a tool for measuring learning outcome is considered valid when it can be used to measure what is supposed to measure. In connection with the educational test, the validity makes it available for measuring learning outcomes.

Azwar implies there are three types of validity, namely content validity; 1) Construct validity and empirical validity: Content validation is the extent to which the elements in a measuring instrument are truly relevant and represent representations of constructs that are in accordance with the measurement objectives. 2) Validity's construct: validity's construct proves whether the measurement results obtained through the test items correlate highly with the theoretical constructs underlying the arrangement ${ }^{26}$. According to this state, Huda \& Mardapi state that construct validity explains the extent to which performance on the test is consistent with the constructs in a particular theoretical consideration $^{27}$. 3) Validity based on criteria: the validity of the criteria is also called empirical validity interpreted as validity determined based on criteria, both internal criteria and external criteria. Internal criteria are

24 H., Retnawati, Validitas, Reliabilitas, dan Karakteristik Butir: Panduan Untuk Peneliti, Mahasiswa, dan Psikometrian (Yogyakarta: Parama Publishing, 2016), p. 16.

25 E.P., Widoyoko, Teknik Penyusunan Instrumen Penelitian (Yogyakarta: Pustaka Pelajar, 2016), p. 141142.

26 S., Azwar, Konstruksi Tes Kemampuan Kognitif (Edisi Kesatu) (Yogyakarta: Pustaka Pelajar, (2016), p. 5

27 Safa'at Ariful Hudha and Djemari Mardapi, 'Developing an Instrument for Measuring the Spiritual Attitude of High School Students', Research and Evaluation in Education, 4.1 (2018), 35-44 <https://doi.org/10.21831/reid.v4i1.20304>. tested that are themselves criteria, while external criteria are the results of measuring instrument or another test outside the instrument itself which are the criteria.

Reynold et. al explained that quality testing is one step to show that evaluation instruments have been optimally developed. The main proof of the quality of the evaluation instrument is its validity. Messick defines validity as "one of integrative on how far the theoretical and rational empirical evidence supports the feasibility of interpretation and action based on the results of the measurement process" ${ }^{\prime 2}$. Validity is an assessment based on various categories of evidence. The relevant proof includes the measure's reliability, whether it includes interest constructs, and whether the score produced correlates with other variables that are expected to correlate with and not correlate with variables that are conceptually different.

According to Yaghmaie validity is used to measure related variables. Validity was a significant factor in identifying the concept of measurement, but it is not an assumption whether the instrument is good to measure what it will measure ${ }^{29}$. Yaghmaie also explained that for a test to be considered a good index validity, the value should be 0.75 or more. A single item with a value lower than 0.75 must be discarded ${ }^{30}$.

\section{Research Method of Validity and Reliability Analysis}

Content reliability in this research can be determined with using classical test theory that indicated by Cronbach's Alpha coefficient, in addition, based on item response theory determined by the total curve of information

28 C. R., Reynold, R. B.,Livingstone, and V., Wilson, Measurement and Assessment in Education (Upper Saddle River: Pearson Education Inc., 2009), p. 23.

29 F Yaghmaie, 'Content Validity and Its Estimation', Journal of Medical Education, 3.1 (2003), 2527 <https://doi.org/10.22037/jme.v3i1.870>

30 Yaghmaie. 
function and standard error of measurement (SEM). Cronbach alpha provides an estimate of the internal consistency of the test instrument, so that (a) alpha does not show the stability or consistency of the test instrument over time, which would be estimated using either the retest-reliability strategy, and (b) alpha does not show stability or consistency in the test all forms of tests, which would be better estimated using the equivalent form a reliability strategy ${ }^{31}$.

The test was conducted on 563 students from 7 high schools. Either reliability or test information function proved the consistency of the test instrument so that the test results can be trusted based on table 1 .

Table 1. Formula Calculation of the Content Reliability Quantitative

\begin{tabular}{|c|c|}
\hline $\begin{array}{l}\text { Alpha Cronbach (Classical test } \\
\text { theory) }\end{array}$ & $\begin{array}{l}\text { Information function and } \\
\text { SEM (Item Response } \\
\text { theory) }\end{array}$ \\
\hline $\begin{array}{l}r_{\mathrm{i}}=\frac{k}{(k-1)}\left\{1-\frac{\sum s_{\mathrm{i}}^{2}}{s_{t}^{2}}\right\} \\
r_{\mathrm{i}}=\text { coefficient reliability } \\
\text { Alfa Cronbach } \\
\mathrm{K}=\text { total question } \\
\sum s_{\mathrm{i}}^{2}=\text { variants total item } \\
s_{\mathrm{t}}^{2}=\text { variants total }\end{array}$ & $\begin{array}{l}\text { to get the standard error } \\
\text { of measurement, first, we } \\
\text { must find the reliability of } \\
\text { the test with this formula: } \\
r_{x y}=1-S_{E}^{2} / S_{x y}^{2} \\
r_{x x y}=\text { reliability } \\
S_{E}^{2}=\text { variance of error } \\
\text { score } \\
S_{x y}^{2}=\text { variance of observing } \\
\text { the score } \\
\text { And this is the formula for } \\
\text { the standard error of } \\
\text { measurement } \\
\text { SEM = } \sqrt{S_{x}^{2}\left(1-r_{x y}\right)} \\
\text { SEM = Standard error of } \\
\text { measurement } \\
r_{x y}=\text { reliability } \\
S_{x}^{2} \\
=\text { variance of observing } \\
\text { the score }\end{array}$ \\
\hline
\end{tabular}

Whereas, in order to make an assessment on content validity, an expert judgment in the

31 James Dean Brown, 'The Cronbach Alpha Reliability Estimate', Shiken: JALT Testing \& Evaluation SIG Newsletter, 6.1 (2002), 17-18. form of quantitative analysis is applied. Quantitative analysis of the content validity using Aiken's V in table 2. Data were obtained from four expert judgment. The four expert judgments consisted of measurement expert, an expert in the Islamic-science, and two Islamic education teachers.

Table 2. Formula Calculation of the Content Validity Quantitatively

\begin{tabular}{|l|}
\hline \multicolumn{1}{|c|}{ Aiken's $\mathrm{V}$} \\
\hline$\sum s /[n(c-1)]$ \\
$\mathrm{s}=\mathrm{r}-$ lo \\
$\mathrm{r}=$ the value given by expert \\
lo = lowest validity score \\
$\mathrm{c}=$ highest validity score \\
$\mathrm{n}=$ number of expert who gave the score
\end{tabular}

The test instrument used the Partial Credit Model (PCM) with four scales. PCM was developed to analysing items that needed some settlement step. According to Istiyono et al., the assumption that using PCM is based on each item have the same different power ${ }^{32}$. Similarly, according to Widiarso, PCM is one of the Rasch models that focuses on the location of the item in the modelling. ${ }^{33}$ The model of PCM can accurate measuring the results of a test by combining dichotomous and polytomous models into one scoring.

\section{Reliability Estimate: a Result}

Estimation reliability with classical test theory of integrated Islamic-science test instrument using the Quest program was shown in Figure 1 where the estimated value was obtained 0.70 .

32 Edi Istiyono, Djemari Mardapi, and Suparno Suparno, 'Pengembangan Tes Kemampuan Berpikir Tingkat Tinggi Fisika (PysTHOTS) Peserta Didik SMA', Jurnal Penelitian dan Evaluasi Pendidikan, 18.1 (2014), $1-12$ <https://doi.org/10.21831/pep.v18i1.2120>.

${ }^{33}$ W., Widiarso, 'Aplikasi Teori Respon Item untuk Pemodelan Respons Menipu pada Skala Kepribadian' \{unpublished research report, Fakultas Psikologi UGM, Yogyakarta. 2010), p. 6. 


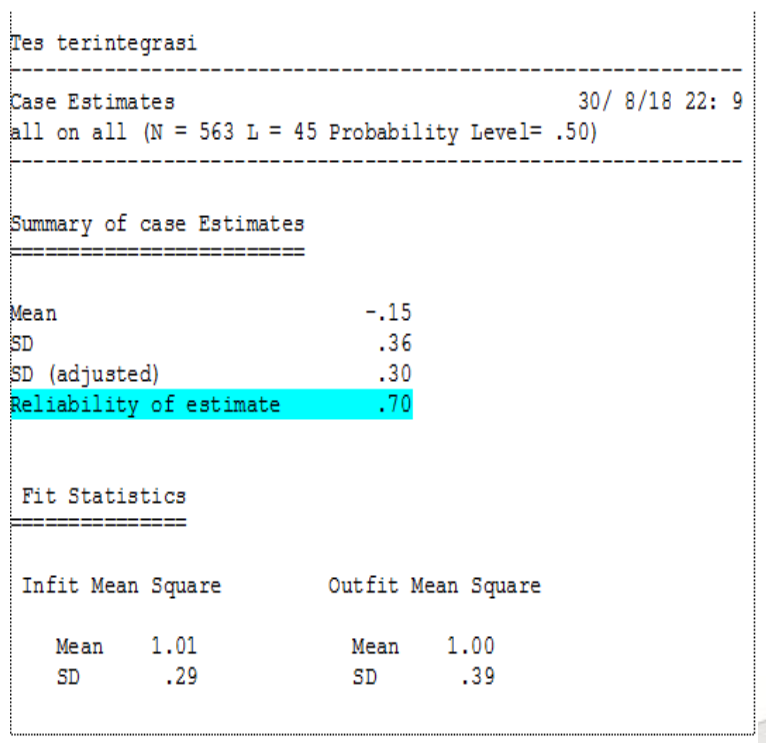

Figure 1. Score Reliability's Estimate with Quest Program

According to Hair, these results show that the test is reliable ${ }^{34}$. If the Alpha Cronbach reliability coefficient is less than 0.70 ( $\mathrm{ri}<$ 0.70), Tavakol \& Dennick Travakol and Dennick in Yusup suggest to revise the items or to eliminate them. The simple method to establish that items are using a computer program. the Alpha Cronbach reliability coefficient is more than 0.90 ( $\mathrm{ri}>0.90$ ), they suggest reducing the number of questions with the same criteria even though in different sentence forms ${ }^{35}$.

Similarly with the result of Alpha Cronbach reliability, depending on the test information function curve and SEM, the coefficient of integrated religious-science test instrument is in the ability range of -1.75 to +3 . These results showed that the test instrument is fit for a student with that range of abilities (between 1.75 to +3 ). The test information function curve was presented in figure 2 .

34 J.F. Hair.

35 Febrinawati Yusup, 'Uji Validitas dan Reliabilitas Instrumen Penelitian Kuantitatif, Jurnal Tarbiyah: Jurnal Ilmiah Kependidikan, 7.1 (2018), 32-45 <https://doi.org/10.18592/tarbiyah.v7i1.2100>.

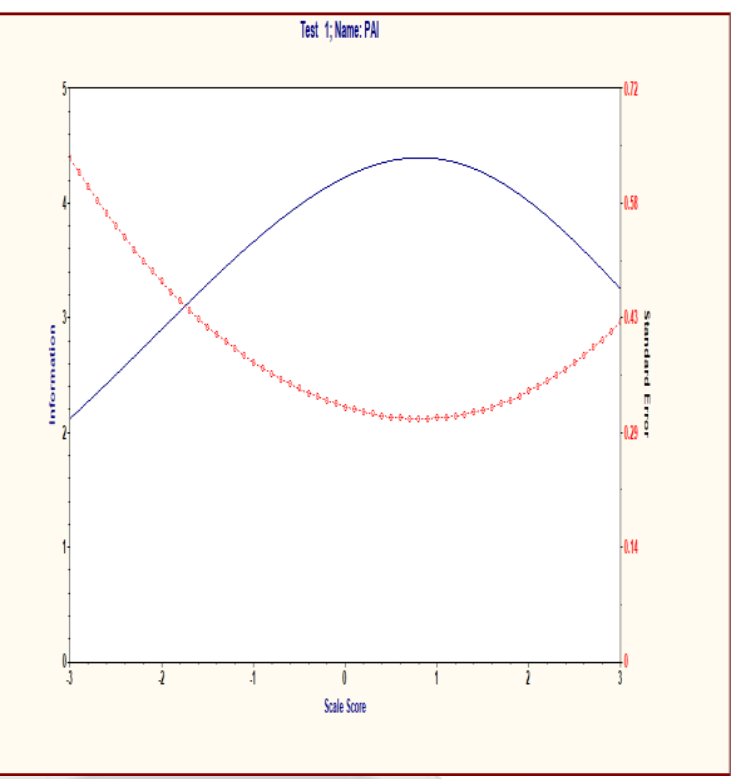

Figure 2. Total Function Information Curve and SEM.

\section{Validity Estimate}

Some improvements on the instrument construction were made based on expert judgment. According to judgment from the expert about the result of the test instrument. Then, the researcher revision the construction of the test. The experts said, focused on the test instrument should be on the aspects universal of subject matter in the Islamic and science, not only at the structure of content material of Islamic-science obtained on the curriculum.

The results of the improvement instrument based on expert judgment are then re-analyzed the content of validity with Aiken' $\mathrm{V}$ index. The results of analysis validity according to the Aiken's $\mathrm{V}$ index are presented in table 3.

Table 3. Result of Validity Instrument According to Aiken's V

\begin{tabular}{|c|c|c|c|c|c|c|c|c|c|c|c|c|}
\hline \multirow{2}{*}{$\begin{array}{l}\text { No. } \\
\text { Item }\end{array}$} & \multicolumn{2}{|c|}{ V1 } & \multicolumn{2}{|c|}{ V2 } & \multicolumn{2}{|c|}{ V3 } & \multicolumn{2}{|c|}{ V4 } & \multicolumn{2}{|c|}{$\begin{array}{l}\text { Total } \\
\text { score }\end{array}$} & \multicolumn{2}{|c|}{$\begin{array}{c}\text { Aiken's } \\
\text { V }\end{array}$} \\
\hline & A & B & A & B & A & B & $\mathrm{A}$ & B & A & B & A & B \\
\hline 01 & 4 & 4 & 5 & 5 & & 5 & 4 & 5 & 17 & 10 & 0,81 & 0,94 \\
\hline 02 & 3 & 3 & 4 & 3 & & 5 & 3 & 3 & 15 & 14 & 0,75 & 0,75 \\
\hline 03 & 3 & 4 & 5 & & & 4 & 3 & & 17 & 18 & 0,81 & 0,88 \\
\hline 04 & 4 & 3 & 5 & 5 & 5 & 4 & 4 & 4 & 18 & 16 & 0,88 & 0,75 \\
\hline
\end{tabular}




\begin{tabular}{|l|l|l|l|l|l|l|l|l|l|l|l|l|}
\hline 05 & 5 & 5 & 5 & 5 & 5 & 5 & 3 & 3 & 18 & 18 & 0,88 & 0,88 \\
\hline 06 & 5 & 5 & 5 & 5 & 4 & 4 & 4 & 4 & 18 & 18 & 0,88 & 0,88 \\
\hline 07 & 5 & 4 & 5 & 4 & 4 & 4 & 4 & 4 & 18 & 16 & 0,88 & 0,75 \\
\hline 08 & 5 & 5 & 5 & 4 & 4 & 4 & 5 & 5 & 19 & 18 & 0.94 & 0,88 \\
\hline 09 & 5 & 4 & 5 & 5 & 5 & 4 & 3 & 5 & 18 & 18 & 0,88 & 0,88 \\
\hline 10 & 5 & 4 & 5 & 5 & 4 & 5 & 4 & 4 & 18 & 18 & 0,88 & 0,88 \\
\hline 11 & 5 & 5 & 5 & 5 & 5 & 5 & 5 & 5 & 20 & 20 & 1 & 1 \\
\hline 12 & 5 & 4 & 5 & 5 & 5 & 5 & 5 & 5 & 20 & 19 & 1 & 0,94 \\
\hline 13 & 4 & 4 & 5 & 5 & 4 & 4 & 4 & 5 & 17 & 18 & 0,81 & 0,88 \\
\hline 14 & 3 & 5 & 4 & 5 & 5 & 3 & 5 & 3 & 17 & 16 & 0,81 & 0,88 \\
\hline 15 & 5 & 5 & 5 & 4 & 5 & 4 & 4 & 4 & 19 & 17 & 0,94 & 0,81 \\
\hline 16 & 3 & 3 & 4 & 4 & 4 & 4 & 5 & 5 & 16 & 16 & 0,75 & 0,75 \\
\hline 17 & 3 & 3 & 5 & 5 & 4 & 4 & 3 & 3 & 15 & 15 & 0,81 & 0,81 \\
\hline 18 & 3 & 4 & 4 & 4 & 5 & 4 & 5 & 4 & 17 & 16 & 0,81 & 0,75 \\
\hline 19 & 3 & 3 & 5 & 5 & 4 & 4 & 4 & 4 & 16 & 16 & 0,81 & 0,75 \\
\hline 20 & 3 & 3 & 5 & 5 & 5 & 4 & 3 & 4 & 16 & 16 & 0,88 & 0,75 \\
\hline 21 & 3 & 3 & 4 & 5 & 5 & 4 & 5 & 5 & 17 & 17 & 0,81 & 0,81 \\
\hline 22 & 3 & 3 & 5 & 4 & 4 & 4 & 4 & 5 & 16 & 16 & 0,75 & 0,75 \\
\hline 23 & 5 & 5 & 5 & 5 & 5 & 5 & 4 & 4 & 19 & 19 & 0,94 & 0,94 \\
\hline 24 & 5 & 3 & 4 & 5 & 3 & 4 & 3 & 4 & 15 & 16 & 0,88 & 0,75 \\
\hline 25 & 3 & 2 & 4 & 4 & 4 & 4 & 4 & 3 & 15 & 13 & 0,75 & 0,75 \\
\hline & Content Validity Test Instrument & & & \\
\hline
\end{tabular}

Based on Aiken's V index, the value of item validity is ranging from 0.75 to 1 . According to Yaghmaie, the value indicates that the instrument is proper to use for measuring and assessing student ability in understanding Islamic-science integrated learning material. Therefore, based on the appropriateness of the content, it can be said that the instrument is ready for use ${ }^{36}$.

The quality of the test instrument can be determined from the criteria of validity and reliability described previously. The developed test instrument have been proved to e valid and reliable so the test instrument is in good quality. In addition, the feasibility of the test instrument is supported by the statement of the Islamic Education teacher as the user and assessor of the instrument that is developed. Seven Islamic education teacher from the different school stated the test instrument is

$$
36 \text { Yaghmaie. }
$$

feasible to use in the learning processes toasses and support the achievement of learning outcomes, especially in Islamic Education. Result of statement Islamic education teacher shown in table 4

Table 4. Results of the Statement of Islamic Education Teachers as Users of Test Instrument

\begin{tabular}{|c|c|c|c|c|}
\hline \multirow[b]{2}{*}{ No. } & \multirow{2}{*}{$\begin{array}{l}\text { PAI } \\
\text { Teachers }\end{array}$} & \multirow{2}{*}{$\begin{array}{l}\text { Name } \\
\text { Schools }\end{array}$} & \multicolumn{2}{|c|}{ Test Instrument } \\
\hline & & & Valid & $\begin{array}{l}\text { Not } \\
\text { Valid }\end{array}$ \\
\hline 1. & Guru PAI 1 & SMAN A & $\sqrt{ }$ & - \\
\hline 2. & Guru PAI 2 & SMAN B & $\sqrt{ }$ & - \\
\hline 3. & Guru PAI 3 & SMAN C & $\sqrt{ }$ & - \\
\hline 4. & Guru PAI 4 & SMAN D & $\sqrt{ }$ & - \\
\hline 5 & Guru PAI 5 & SMAN E & $\sqrt{ }$ & - \\
\hline 6 & Guru PAI 6 & SMAN F & $\sqrt{ }$ & - \\
\hline 7. & Guru PAI 7 & SMAN G & $\sqrt{ }$ & - \\
\hline
\end{tabular}

\section{Conclusion}

Content validity of Integrated IslamicScience of the test instrument is classified good according to the Aiken index amount from the assess of four experts, which is in the ranging of 0.75 to 1 . All items in the test instrument developed proved to be fit. Reliability of the test also classified to good test instrument expressed by Cronbach Alpha coefficient of 0.70. Furthermore, based on the total item function information and standard error of measurement, it is known that the test instrument is fit (suitable) for a student with ability ranging from -1.75 to +3 . In addition, Seven Islamic education teacher from the different school stated that the test instrument is feasible to use in the learning processes toasses and support the achievement of learning outcomes, especially in Islamic Education.

\section{References}

\section{Books}

Anderson, L.W., D. R, Krathwohl, Kerangka Landasan untuk Pembelajaran, Pengajaran, dan Asesmen (Revisi Taksonomi Pendidikan Bloom), cetakan kedua (terjemahan 
Agung Prihantoro) (Yogyakarta: Pustaka Pelajar, 2017)

Azwar, S., Constructing Psychological Scale (Yogyakarta: Pustaka Pelajar, 2017)

-, Konstruksi Tes Kemampuan Kognitif, edisi kesatu (Yogyakarta: Pustaka Pelajar, (2016)

Hair, J.F., et.al., Multivariate Data Analysis 7th Edition (New York: Pearson Prentice Hall, 2010)

Mardapi, Djemari, Pengukuran, Penilaian dan Evaluasi Pendidikan (Yogyakarta: Parama Publishing, 2016)

Retnawati, H., Validitas, Reliabilitas, dan Karakteristik Butir: Panduan Untuk Peneliti, Mahasiswa, dan Psikometrian (Yogyakarta: Parama Publishing, 2016), p. 16.

Subali, B., Pengembangan Tes: Beserta Penyelidikan Validitas dan Reliabilitas Secara Empiris (Yogyakarta: UNY Press, 2016)

Suryabrata, S., Pengembangan Alat Ukur Psikologi (Edisi Ketiga) (Yogyakarta: Penerbit Andi, 2005)

Team Publish, Salinan Undang- Undang No. 20 Tabun 2003 tentang Sistem Pendidikan Nasional (Jakarta: Nusa Press, 2017)

Wagner, T., The Global Achierment Gap (New York: Basic Book, 2008)

Wells, Craig S., James A. Wollack, An Instructor's Guide to Understanding Test Reliability: Testing \&o Evaluation Services (UK: University of Wisconsin, 2003)

Widoyoko, E.P., Teknik Penyusunan Instrumen Penelitian (Yogyakarta: Pustaka Pelajar, 2016)

\section{Journals}

Aiken, Lewis R., 'Three Coefficients for Analyzing the Reliability and Validity of Ratings', Educational and Psychological Measurement, 45 (1985), 131-42 $<$ https://doi.org/10.1177/00131644854 51012>

Hudha, Safa'at Ariful, and Djemari Mardapi, 'Developing an Instrument for
Measuring the Spiritual Attitude of High School Students', Research and Evaluation in Education, 4 (2018), 35-44 $<$ https://doi.org/10.21831/reid.v4i1.203 04>

Istianah, Euis, 'Meningkatkan Kemampuan Berpikir Kritis dan Kreatif Matematik dengan Pendekatan Model Eliciting Activities (MEAS) pada Siswa SMA', Infinity Journal, 2 (2013), 43 $<$ https://doi.org/10.22460/infinity.v2i1. $23>$

Istiyono, Edi, Djemari Mardapi, and Suparno Suparno, 'Pengembangan Tes Kemampuan Berpikir Tingkat Tinggi Fisika (PysTHOTS) Peserta Didik SMA', Jurnal Penelitian dan Evaluasi Pendidikan, 18 (2014), 1-12 <https://doi.org/10.21831/pep.v18i1.21 $20>$

James Dean Brown, 'The Cronbach Alpha Reliability Estimate', Sbiken: JALT Testing \& Evaluation SIG Newsletter, 6 (2002), 1718

Kunter, Mareike, Uta Klusmann, Jürgen Baumert, Dirk Richter, Thamar Voss, and Axinja Hachfeld, 'Professional Competence of Teachers: Effects on Instructional Quality and Student Development', Journal of Educational Psychology, 105 (2013), 805-20 < https://doi.org/10.1037/a0032583>

Mumtahanah, Nurotun, 'Meningkatkan Kemampuan Berpikir Kritis Siswa Melalui Metode Cooperative Learning dalam Pembelajaran PAI', Al Hikmah: Jurnal Studi Keislaman, 3 (2013), 4

Pradana, Shan Duta Sukma, Parno Parno, and Supriyono Koes Handayanto, 'Pengembangan Tes Kemampuan Berpikir Kritis pada Materi Optik Geometri untuk Mahasiswa Fisika', Jurnal Penelitian dan Evaluasi Pendidikan, 21 (2017), <https://doi.org/10.21831/pep.v21i1.13 $139>$

Quitadamo, Ian, Celia Faiola, James E. Johnson, and Martha J. Kurtz, 
'Community-Based Inquiry Improves

Critical Thinking in General Education Biology', CBE Life Sciences Education, 7 (2008), $327-37$ $<$ https://doi.org/10.1187/cbe.07-110097>

Suwarto, S, 'Pengembangan Tes Ilmu Pengetahuan Alam Terkomputerisasi, Jurnal Penelitian dan Evaluasi Pendidikan, 21 (2017),

$<$ https://doi.org/10.21831/pep.v21i2.13 144>

Yaghmaie, F, 'Content Validity and Its Estimation', Journal of Medical Education, 3 (2003), $25-27$ <https://doi.org/10.22037/jme.v3i1.870 $>$

Yusup, Febrinawati, 'Uji Validitas dan Reliabilitas Instrumen Penelitian Kuantitatif, Jurnal Tarbiyah: Jurnal Ilmiah Kependidikan, 7 (2018), 32-45 $<$ https://doi.org/10.18592/tarbiyah.v7i1 $.2100>$

\section{Other references}

Hove, G., 'Developing Critical Thinking Skills in The High School English Classroom' \{unpublished magister thesis, University of Wisconsin-Stout, 2011\}

Widiarso, W., 'Aplikasi Teori Respon Item untuk Pemodelan Respons Menipu pada Skala Kepribadian' \{unpublished research report, Fakultas Psikologi UGM, Yogyakarta. 2010\}

Yusri, 'Keterkaitan Scientific Learning dengan Kemampuan Berpikir Kritis (Kajian Proses Pembelajaran di Sekolah Dasar Budi Mulia Dua Sedayu Bantul)' \{unpublished magister thesis, Program Pascasarjana UIN Sunan Kalijaga, Yogyakarta, 2015\} 